\title{
Nutritional state of patients with lung cancer undergoing thoracotomy
}

\author{
Y Bashir, T R Graham, A Torrance, G J Gibson, P A Corris
}

\begin{abstract}
Preoperative nutritional assessment was carried out on 39 consecutive patients with bronchial carcinoma who underwent thoracotomy. For 18 patients the body mass index and triceps and subscapular skinfold thickness fell below the 25 th centile. In 23 patients the creatinine height index was less than $80 \%$ of the predicted value. The mean (SEM) serum albumin concentration was $40.3(0.57) \mathrm{g} / 1$ (reference range $35-50 \mathrm{~g} / \mathrm{l}$ ) and mean (SEM) serum transferrin $1.77(0.1) \mathrm{g} / 1$ (reference range $2 \cdot 0-3 \cdot 0 \mathrm{~g} / \mathrm{l}$ ). Although only three patients were hypoalbuminaemic, transferrin concentrations were depressed in 26 patients. There was a significant fall in the serum concentrations of both prealbumin and transferrin in the first postoperative week. Nutritional insufficiency was particularly severe in the four patients who developed an early bronchopleural fistula. It is concluded that protein-energy malnutrition is common in patients with operable bronchial carcinoma and that routine postoperative feeding does not prevent further depletion of circulating proteins. A larger prospective study is needed to examine the relation between preoperative nutritional state and outcome.
\end{abstract}

Protein-energy malnutrition is common in patients requiring surgery ${ }^{12}$ and is associated with increased perioperative morbidity and mortality. ${ }^{3-6}$ Controlled studies suggest that preoperative identification and treatment of nutritional deficiencies may improve the outcome of surgery, ${ }^{7-9}$ and this has fostered a growing awareness of methods of nutritional assessment and support among general surgeons. $^{10}$

Little attention has so far been paid to the state of nutrition of patients undergoing pulmonary surgery. Most patients are smokers undergoing thoracotomy for bronchial carcinoma, and as malignancy ${ }^{11}$ and chronic airflow limitation ${ }^{12}$ predispose to malnutrition these patients might be expected to be at increased risk of nutritional deficiencies. Conceivably such nutritional deficiencies will influence adversely the postoperative course of some patients whose tumours are successfully resected; this could result from impaired tissue healing, ${ }^{13}$ undue susceptibility to infection, ${ }^{14}$ and possibly respiratory muscle dysfunction. ${ }^{15}$
Nutritional assessment by clinical intuition has been largely superseded by standardised techniques with reference values derived from population studies. ${ }^{16}$ Various anthropometric, biochemical, and functional tests may be used to assess the state of the major body compartments-that is, energy stores (mostly fat), somatic protein mass (skeletal muscle), and visceral protein mass (reflected by the serum concentrations of transport proteins synthesised in the liver). As deficiencies of the individual compartments usually coexist, the term protein-energy malnutrition is often used. We have conducted a survey of the nutritional state of patients with bronchial carcinoma before surgery to establish the prevalence of protein-energy malnutrition in this population.

\section{Methods}

Thirty nine consecutive patients with bronchial carcinoma underwent thoracotomy at the Regional Cardiothoracic Centre, Freeman Hospital, Newcastle upon Tyne, over three months. Their mean age was 61.9 years and mean (SD) $\mathrm{FEV}_{1}$ was $2.26(0.65)$ litres or $79.7 \%$ predicted. Twenty three patients underwent lobectomy and 12 pneumonectomy, and four were found to have an unresectable tumour at thoracotomy. The histological diagnosis was squamous cell carcinoma in 21 cases, adenocarcinoma in 14, and large cell undifferentiated carcinoma in four.

We screened all patients for evidence of protein-energy malnutrition before operation, using a panel of anthropometric and biochemical indicators that are widely accepted. ${ }^{1617}$ For analysis of the results for each variable the patients were treated as a group; we did not derive a multivariable nutritional assessment index for individual patients.

Energy reserves were estimated from the body mass index and the sum of triceps and subscapular skinfold thickness. ${ }^{1617}$ The body mass index was calculated by dividing the patient's weight $(\mathrm{kg})$ by the square of the height (m). Skinfold measurements were made by one operator with standard calipers, who took the average of three recordings at each site. The results obtained for the body mass index and triceps-subscapular skinfold thickness were compared with values in standard reference tables and expressed as percentiles after correction for age and sex..$^{16-19}$ For comparison, the weight-height data were also expressed as percentages of ideal body weight. ${ }^{16} 17$

Protein was assessed on the basis of the creatinine height index ${ }^{20}$ and serum concentra- 
tions of albumin and transferrin..$^{21} 22$ The creatinine height index (reflecting somatic protein mass ${ }^{16}$ ) was obtained by expressing the patient's urinary creatinine excretion as a percentage of a reference value corrected for sex and height. ${ }^{20}$ Creatinine excretion was measured in a 24 hour urine collection carried out in the ward before the day of surgery. Serum albumin concentration was determined by a standard colorimetric method and serum transferrin and prealbumin concentrations by radial immunodiffusion.

To assess the adequacy of nutritional support, we made serial measurements of serum transferrin and prealbumin: the baseline serum sample taken on the day before surgery (day 0 ) was followed by further samples on the second, fourth, and six postoperative days (days 2, 4, and 6 ). Both of these proteins have a relatively short circulating half life (transferrin eight days, prealbumin two days) and so their concentrations change measurably in response to acute nutritional stresses ${ }^{23}$ providing a crude index of nitrogen balance. ${ }^{24}$

Finally, we recorded all major complications.

\section{Results}

ANTHROPOMETRIC MEASUREMENTS

The distribution of body mass indices and triceps-subscapular skinfold thicknesses showed a substantial skew towards the lower percentile bands, 18 patients falling below the 25th percentile (fig $1 a$ and $1 b$ ). When the weight-height data were expressed as percentages of ideal body weight eight patients were in the range $80-90 \%$ and six patients were below $80 \%$.

\section{CREATININE HEIGHT INDEX}

Twenty three patients had a creatinine height index below $80 \%$ predicted (fig $1 \mathrm{c}$ ) and eight patients had values below $60 \%$. (a)

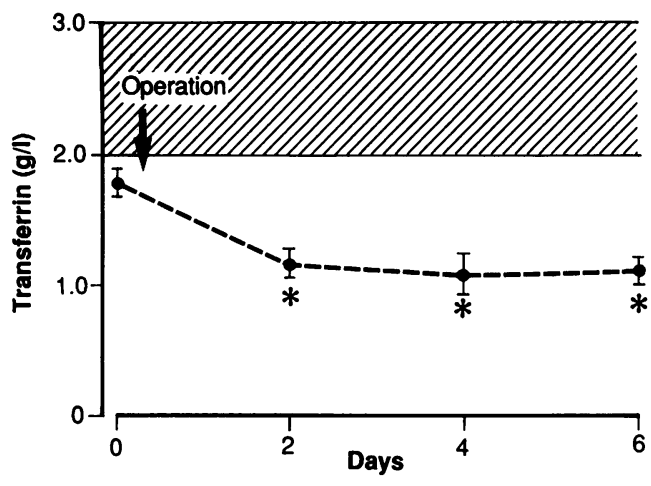

(b)

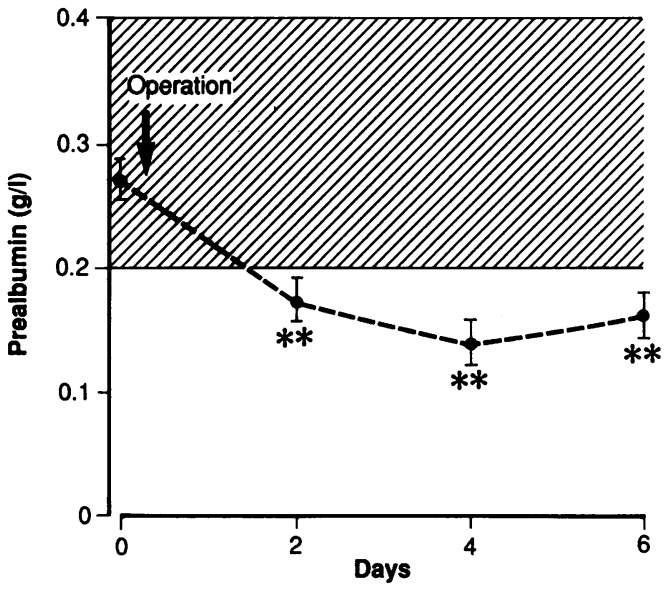

Figure 2 (a) Serum transferrin and (b) serum prealbumin concentrations before surgery (day 0 ) and on days 2, 4, and 6 after surgery. All values are expressed as means with SEM. The reference range (hatched) is 2.0$3.0 \mathrm{~g} / \mathrm{l}$ for transferrin and $0.2-0.4 \mathrm{~g} / \mathrm{l}$ for prealbumin. Asterisks indicate significant change $(p<0.001$, paired $t$ test) from day 0.

SERUM PROTEINS

The mean (SEM) serum albumin concentration for the group was $40.3(0.57) \mathrm{g} / \mathrm{l}$; only three patients had values below $35 \mathrm{~g} / 1$ (reference (a) Body mass index

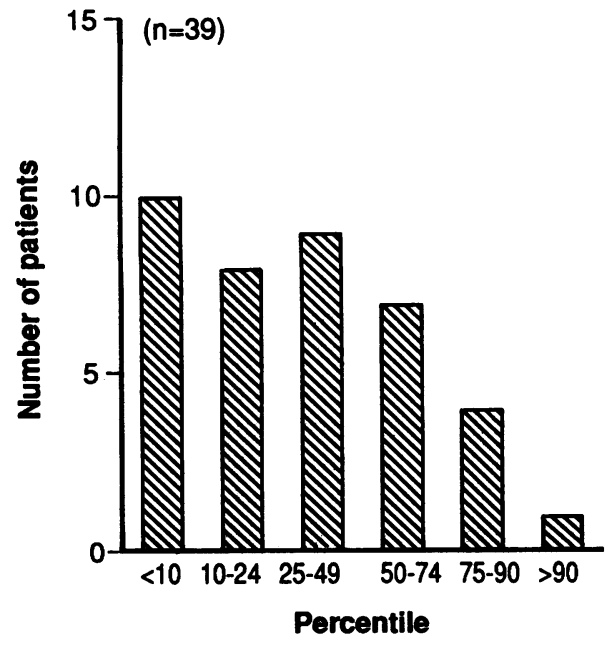

(b) Triceps-subscapular skinfold thickness

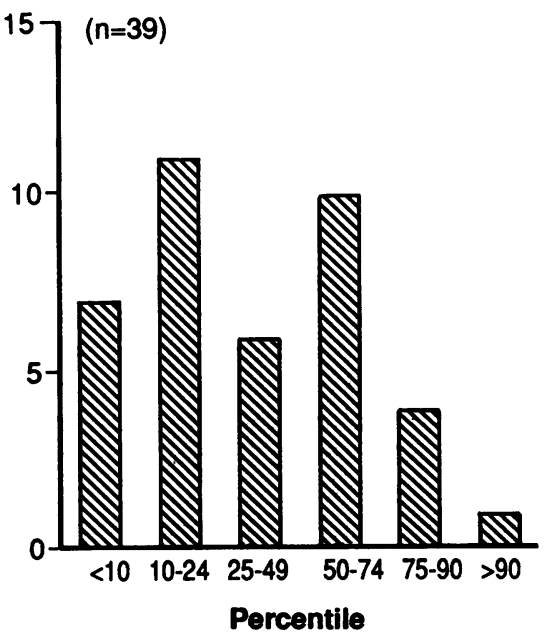

(c) Creatinine height index

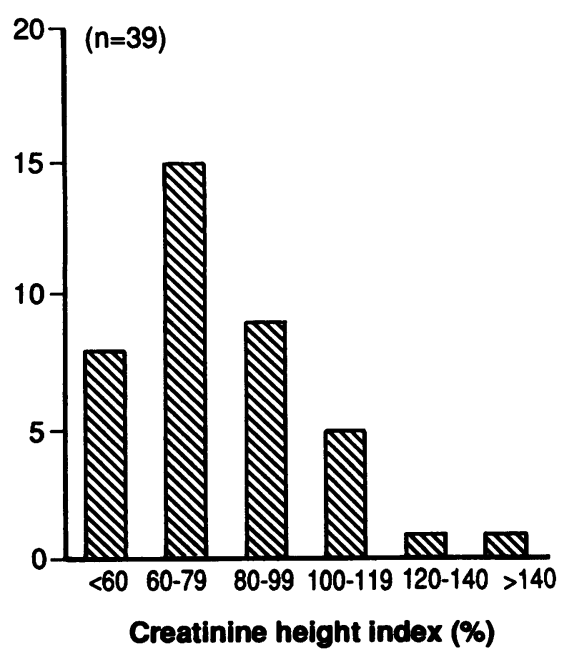

Figure 1 Distribution of $(a)$ body mass index, (b) triceps-subscapular skinfold thickness, and (c) creatinine height index according to percentage band from a reference population $($ mean $=100 \%$ ). 
Preoperative nutritional indices of the patients who developed bronchopleural fistula

\begin{tabular}{llllll}
\hline $\begin{array}{l}\text { Patient } \\
\text { No }\end{array}$ & $\begin{array}{l}\text { BMI } \\
\text { centile }\end{array}$ & $\begin{array}{l}\text { Skinfold } \\
\text { centile }\end{array}$ & CHI $(\%)$ & $\begin{array}{l}\text { Albumin } \\
(\mathrm{g} / \mathrm{l})\end{array}$ & $\begin{array}{l}\text { Transferrin } \\
(\mathrm{g} / \mathrm{l})\end{array}$ \\
\hline 3 & $<10$ & $<10$ & $41 \cdot 3$ & 40 & 1.90 \\
11 & $<10$ & $10-25$ & $72 \cdot 8$ & 38 & 1.43 \\
17 & $10-25$ & $25-50$ & 67.0 & 42 & 1.81 \\
33 & $<10$ & $<10$ & 65.7 & 42 & 1.40 \\
\hline
\end{tabular}

* Serum concentration; reference range $35-50 \mathrm{~g} / 1$ for albumin and $2 \cdot 0-3.0 \mathrm{~g} / \mathrm{l}$ for transferrin. BMI-body mass index; skinfold-sum of triceps and subscapular skinfold thickness; $\mathrm{CHI}-$ creatinine height index.

range $35-50 \mathrm{~g} / \mathrm{l}$ ). By contrast, mean (SEM) serum transferrin was reduced at $1 \cdot 77(0 \cdot 1) \mathrm{g} / 1$ (reference range $2 \cdot 0-3.0 \mathrm{~g} / \mathrm{l}$ ) and 26 patients had values below the reference range. There was a significant fall in transferrin and prealbumin from day 0 to day 2 ( $\mathrm{p}<0.001$, paired $t$ test; fig 2), and the concentrations of both proteins were still low on day 6 . This fall was seen in patients with normal as well as subnormal preoperative values.

\section{COMPLICATIONS}

The following major postoperative complications developed: pneumonia (eight patients), bronchopleural fistula (four), haemorrhage (one), pulmonary embolus (one). There were three deaths. Bronchopleural fistula, fatal in two of the four cases, occurred more frequently than expected. In all four patients complete resection of the tumour had been achieved. All four had evidence of gross protein-energy malnutrition in the preoperative screening, though none was hypoalbuminaemic (table). There was no clear association between preoperative malnutrition and any other postoperative complication.

\section{Discussion}

Various anthropometric, biochemical, and functional tests have been proposed to assist in the diagnosis of protein-energy malnutrition, ${ }^{1617}$ but there is no general agreement about the best approach for nutritional assessment of individual patients. ${ }^{61625}$ The prevalence of nutritional deficiencies in a population, however, can be estimated by using several nutritional indices in all subjects and comparing the distribution of values for each index with that in a normal population. This approach avoids the problems associated with defining the nutritional state of individual patients. Although the reference tables are derived from white North Americans, ${ }^{16-19}$ this is unlikely to lead to a large discrepancy when they are applied to a broadly similar population such as the one that our patients were drawn from. These standards are widely used for clinical assessment by dieticians and nutritional scientists in Britain. ${ }^{17}$

Our results suggest that protein-energy malnutrition is common in patients with operable bronchial carcinoma. Serum albumin concentration is the only one of these nutritional indices routinely available to clinicians, but this was normal in 36 of the 39 patients. Like Mullen et $a l,{ }^{26}$ we found serum transferrin concentration to be a more sensitive biochemical index of protein depletion. The low frequency of hypoalbuminaemia may have contributed to a tendency to underestimate the nutritional problems of such patients in the past.

Several factors may have contributed to the nutritional deficiencies in these patients. Malignant tumours may cause cachexia by various mechanisms even before the development of metastases. ${ }^{11}$ Chronic airflow limitation is known to predispose to malnutrition, ${ }^{12}$ though the mean $\mathrm{FEV}_{1}$ was $80^{\circ}$ o predicted and none of the patients had evidence of severe emphysema. Chronic heavy tobacco consumption may also be associated with a poor dietary intake independently of bronchial carcinoma or emphysema.

The fall in serum transferrin and prealbumin in the week after surgery was probably due to a combination of inadequate postoperative feeding and the catabolic effects of surgery on protein metabolism. ${ }^{27}$ In uncomplicated cases patients were allowed an unrestricted diet from 24-48 hours after surgery, but it would often take several more days for their dietary intake to return to normal. This may have important implications for tissue healing. Recent evidence suggests that wound healing is extremely sensitive to short term reductions in nutritional intake and may become impaired without there being evidence of major protein-energy malnutrition, ${ }^{13}$ while in malnourished patients nutritional repletion enhances wound healing long before there is any measurable restoration of protein and energy stores. ${ }^{28}$

The unusually high incidence of bronchopleural fistula was probably due to chance clustering of cases; the overall incidence of this complication in our centre is much lower. Nevertheless, it is of interest that all four patients had evidence of multiple nutritional deficiencies (table), raising the possibility that malnutrition may have been one factor contributing to the development of this complication-for example, by adverse effects on healing of the bronchial stump. ${ }^{23}$ To confirm this, however, would need a prospective comparison of outcome in patients of differing preoperative nutritional state (see below).

If the use of nutritional screening techniques in the preoperative workup of patients with bronchial carcinoma is to be justified we need to show that the techniques identify individual patients with an increased likelihood of developing complications and that nutritional support improves the outcome in these "high risk" patients. Proving a relation between protein-energy malnutrition and outcome would require a larger prospective study looking at the nutritional state of individual patients as opposed to the population approach adopted in this survey. Numerous methods have been proposed for assessing individual patients, including elaborate formulae for multivariable indices. ${ }^{35}$ General surgical experience, however, suggests that high risk patients can be just as accurately identified by measuring serum transferrin and a functional test such as handgrip or respiratory muscle strength. ${ }^{625} 29$ These patients could be entered into a prospective trial to assess the benefit of nutritional 
interventions, such as outpatient dietary supplementation and perioperative hyperalimentation with enteral tube feeding. Experience in other groups of patients suggests that it might be possible to reduce morbidity and perhaps mortality by such measures, ${ }^{7-9}$ though substantial numbers of patients may be required to show an effect. ${ }^{30}$

We are indebted to $\mathrm{Mr}$ A Hedley-Brown, $\mathrm{Mr}$ C J Hilton, and Mr G N Morritt for allowing access to their patients. We are also grateful to the nursing staff and physiotherapists of the Regional Cardiothoracic Centre, Freeman Hospital, for their assistance with data collection.

1 Bistrian RB, Blackburn GL, Halowell $\mathrm{H}$, Heddle RJ Protein status of general surgical patients. JAMA 1974;230:858-60.

2 Willcutts HD. Nutritional assessment of 1000 surgical patients in an affluent suburban community hospital. Parent Ent Nutr 1977;1:25.

3 Harvey KB, Moldawer BS, Bistrian RB, et al. Biological measures for the formulation of a hospital prognostic measures for the formulation of a ho

4 Mullen JL. Consequences of malnutrition in surgical patients. Surg Clin N Am 1981;61:465-87.

5 Buzby GP, Mullen JP, Matthews DC, et al. Prognostic nutritional index in gastrointestinal surgery. Am J Surg 1980;139:160-7.

6 Dempsey DT, Mullen JL, Buzby GP. The link between nutritional status and clinical outcome: can nutrition intervention modify it? Am J Clin Nutr 1988;47:352-6.

7 Mullen JL, Buzby GP, Matthews DC, et al. Reduction of operative morbidity and mortality by combined preoperative and post-operative nutritional support. $A n n$ Surg 1981;192:604-13.

8 Muller JM, Brenner U, Dienst C, ét al. Preoperative parenteral feeding in patients with gastrointestinal carciparenteral feeding in patients

9 Heatley RV, Lewis MH, Williams RHP, et al. Preoperative intravenous feeding - a controlled study. Postgrad Med J 1979;55:541-5.

10 Irving M. Enteral and parenteral nutrition. $\mathrm{Br} \mathrm{Med} J \mathrm{1985}$; 291:1369-42.
11 Holroyde CP, Reichard GA Jr. General metabolic abnormalities in cancer patients. Surg Clin N Am 1986; 66:947-54.

12 Wilson DO, Rogers RM, Hoffman RM. Nutrition and chronic lung disease. Am Rev Respir Dis 1985;132: 1347-65.

13 Haydock DA, Hill GL. Impaired wound healing in surgical patients with varying degrees of malnutrition. J Parent patients with varying degr

14 Superina R, Meakins JL. Delayed hypersensitivity, anergy and the surgical patients. $J$ Surg Res 1984;37:151-74.

15 Rochester DF, Esau SA. Malnutrition and the respiratory system. Chest 1984;85:411-5.

16 Grant JP, Cyster PB, Thurlow J, et al. Current techniques of nutritional assessment. Surg Clin N Am 1981;61:437-63.

17 Thomas B, ed. Manual of dietetic practice. Oxford: Blackwell, 1988:59-65.

18 Department of Health, Education and Welfare. Vital and health statistics. Weight and height of adults, 18-74 years of age, United States, 1971-74. Washington DC: Government Printing Office, 1979.

19 Cronk CE, Roche AF. Race and sex-specific data for triceps/ subscapular skinfolds and weight/stature ${ }^{2}$. Am J Clin Nutr subscapular skin

20 Bistrian BR, Blackburn GL, Sherman M, Scrimshaw NS. Therapeutic index of nutritional depletion in hospitalized patients. Surg Gyn Obstet 1975;141:512-6.

21 Golden MHN. Transport proteins as indices of protein status. Am J Clin Nutr 1982;35:1159-65.

22 Young GA, Hill GL. Assessment of protein-calorie malnutrition in surgical patients from plasma proteins and anthropometric measurements. Am J Clin Nutr 1978;31: 429-35.

23 Shetty PS, Watrasiewicz KE, Jung RT, et al. Rapid turnover transport proteins: an index of subclinical protein-energy malnutrition. Lancet 1979;ii:230-2.

24 Smale BF, Hobbs CL, Mullen JL, Rosato EF. The relationship of nitrogen balance to changes in serum proteins. $J$ ship of nitrogen balance to cha

25 Hill GL. Malnutrition and surgical risk: guidelines for Hill GL. Malnutrition and surgical risk: guidelines for 26 Mullen JL, Gertner MH, Buzby GP, et al. Implications of malnutrition in the surgical patient. Arch Surg 1979;114 121-5.

27 Stein TP, Buzby GP. Protein metabolism in surgical patients. Surg Clin N Am 1981;61:519-27.

28 Windsor JA, Knight GS, Hill GL. Wound healing response in surgical patients: recent food intake is more importan than nutritional status. Br J Surg 1988;75:135-7.

29 Boraas M, Peterson O, Knox L, et al. Serum proteins and outcome in surgical patients [abstract]. J Parent Ent Nutr 1982;6:585.

30 Buzby GP, Williford WO, Peterson O, et al. A randomized clinical trial of TPN in malnourished surgical patients: the rationale and impact of previous clinical trials and pilo study on protocol design. Am J Clin Nutr 1988;47:357-65. 